\title{
Publisher Correction: Copper adparticle enabled selective electrosynthesis of n-propanol
}

Jun Li 1 , Fanglin Che, Yuanjie Pang, Chengqin Zou, Jane Y. Howe, Thomas Burdyny (D, Jonathan P. Edwards,

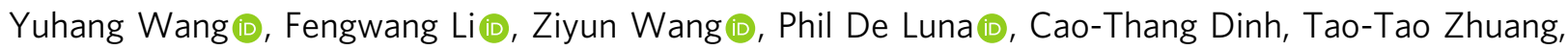
Makhsud I. Saidaminov, Shaobo Cheng, Tianpin Wu, Y. Zou Finfrock, Lu Ma (D), Shang-Hsien Hsieh (D), Yi-Sheng Liu (D), Gianluigi A. Botton (D), Way-Faung Pong, Xiwen Du, Jinghua Guo (D), Tsun-Kong Sham, Edward H. Sargent (1) \& David Sinton (D)

Correction to: Nature Communications https://doi.org/10.1038/s41467-018-07032-0, published online 5 November 2018.

The original version of this Article incorrectly omitted the received/accepted dates of Received: 05 June 2018 ; Accepted: 10 October 2018. This has now been corrected in the PDF and HTML versions of the Article.

Published online: 20 February 2020

(c) (i) Open Access This article is licensed under a Creative Commons Attribution 4.0 International License, which permits use, sharing, adaptation, distribution and reproduction in any medium or format, as long as you give appropriate credit to the original author(s) and the source, provide a link to the Creative Commons license, and indicate if changes were made. The images or other third party material in this article are included in the article's Creative Commons license, unless indicated otherwise in a credit line to the material. If material is not included in the article's Creative Commons license and your intended use is not permitted by statutory regulation or exceeds the permitted use, you will need to obtain permission directly from the copyright holder. To view a copy of this license, visit http://creativecommons.org/licenses/by/4.0/. 